\title{
Occurrence and Frequency of Outdoor and Indoor Airborne Fungi of Suez General Hospital, Suez, Egypt
}

\author{
Abdel-Hamied M. Rasmey*, Akram A. Aboseidah, Eman M. El-Bealy \\ Department of Botany and Microbiology, Faculty of Science, Suez University, Suez, Egypt
}

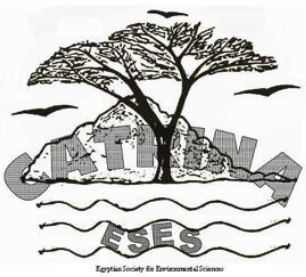

This study aimed to determine the occurrence and frequency of fungi in the outdoor and indoor (reception and intensive care) air of Suez General Hospital as well as to investigate the antifungal activity of some volatile oils against isolated toxigenic species. Samples were collected through passive sedimentation using settle plate method. Sabouraud dextrose agar (SDA) plates were exposed to air and incubated at $28^{\circ} \mathrm{C}$ for 7 days. 39 species represents 13 fungal genera were isolated from the outdoor and indoor air and the most common genera were Aspergillus, Penicillium, Cladosporium, Alternaria, and Rhizopus. The total colony forming units of airborne fungi of the outdoor, reception, and intensive care unit (ICU) were $2063.25,1395.15$, and $884.25 \mathrm{CFU} / \mathrm{m}^{3}$, respectively. Aspergillus flavus recorded the highest occurrence with the highest frequency in the outdoor and indoor air and produced aflatoxins $\mathrm{B}^{1}$ and $\mathrm{B}^{2}$. Cinnamon essential oil showed high antifungal activity against the isolated toxigenic fungi and its fumigation inhibited the germination of spores of these fungi.

keywords: Bioaerosols, Contamination, Mycotoxins, Fumigation, Antifungal, Cinnamon.

\section{INTRODUCTION}

The progressive increase of fungal infections in hospitals and the high rates of morbidity and mortality with which they are associated in the last years encourage the researchers worldwide to study and identify the bioaerosols. Monitoring of bioaerosols in hospitals can give information for epidemiological examination of nosocomial infectious diseases, control of airborne fungi and as a quality control indicator (Li and Hou 2003; Cent-eno and Machado, 2004; Fernstrom and Goldblatt, 2013). Several studies have been conducted on the fungal contamination in outdoor and indoor environ-ments of the hospitals because most outbreaks of nosocomial fungal diseases have been attributed to airborne fungi from sources outside of the hospital (Dacarro et al., 2003; Vonberg and Gastmeier, 2006; Goudarzi et al., 2017; Rostami et al., 2017).

It has been reported that several fungi from different environmental sources may disperse over great distances by air currents and may be inhaled, ingested, or come in direct contact with individuals who have no contact with the infectious source. In indoor environments, the main source for microbes is usually the outdoor air $(\mathrm{Su}$ et al., 2001; Shelton et al., 2002). In the indoor air, microbes come and go, which is a natural phenomenon. Ventilation and cleaning are the usual removal processes of microbes in indoor environments. However, microbes may also grow indoors on building materials and structures. In such a situation, they may be responsible for different harmful effects causing negative aesthetic effects such as dirty appearance and unpleasant odors (Portnoy et al., 2005). Although indoor environment may help in the occurrence and distribution of indoor fungi by growing them on building materials, flower pots, foodstuffs, house dust and pet bedding materials (Araujo and Cabral, 2010). The fungal genera Aspergillus, Penicillium, Cladosporium and Alternaria are the most dominant fungi in the atmosphere of hospitals and are potential human pathogens (Rainer et al., 2000).

Undoubtedly, the main concern about microbial growth in indoor environments is related to the strong link to the adverse health effects in the occupants (Douwes and Pearce, 2003; Li and Yang, 2004). The importance of airborne fungi has been increased not only due to the health hazards caused by the spores themselves but also for their secondary metabolites. The airborne fungi may secrete numerous toxic secondary metabolites which can be harbored by the spores and causes toxicity when entering the host body (Araujo and Cabral, 2010). In addition, several volatile organic compounds and oils may be secreted by these fungi and their fumigation affects human health. Therefore, it is necessary to characterize and identify the contaminated microbes in the indoor environments of hospitals and to study their temporal fluctuation to achieve a more accurate exposure assessment of patients. So, the present investigation aimed to identify the common outdoor and indoor fungi of the Suez General Hospital.

\section{MATERIALS AND METHODS}

\section{Sampling sites}

The air sampling was carried out in triplicates during six visits at Suez General Hospital, Suez Governorate, and Egypt. Sampling was carried out in three different sectors; two different indoor sites (hospital reception and intensive care unit) and an outdoor site (hospital garden).

\section{Air sampling and isolation of fungi}

Air sampling from the different sectors at the hospital was performed at mid-day (hospital working time) using the settle plate method according to Hoekstra et al. (2004). Sabouraud dextrose agar (SDA) medium supplemented with chloroamphenicol $(50 \mu \mathrm{g} / \mathrm{ml})$ and rose 
bengal $(10 \mu \mathrm{g} / \mathrm{ml}$ ) (in order to minimize the appearance of bacteria) was used for catching and isolation of airborne fungi from the target hospital. The plates were exposed for 15 minutes in each exposure, positioned 170 $\mathrm{cm}$ height (roughly human respiration height) and then sealed and incubated at $28^{\circ} \mathrm{C}$ for 7 days. The appeared fungi were expressed as colony forming units per cubic meter of air $\left(\mathrm{CFU} / \mathrm{m}^{3}\right)$ and estimated according to the equation, $\mathrm{CFU} / \mathrm{m}^{3}=\mathrm{a} \cdot 10000 / \mathrm{p} \cdot \mathrm{t} \cdot 0.2$ (StryjakowskaSekulska et al., 2007). Where: a $=$ the number of colonies on the Petri plate, $\mathrm{p}=$ the surface area of the Petri plate, $0.2=$ constant and $t=$ the time (duration) of Petri plate exposure.

\section{Identification of the isolated fungi}

All the isolated filamentous fungi were identified to the genus, species and varieties level based on the macroscopic features of their colonies and the microscopic morphological characteristics of their spores and hyphae according to Moubasher (1993) for fungi in general, Raper and Fennell (1965) for Aspergillus spp., Booth (1977) for Fusarium spp., Domsch et al. (1980) for fungi in general, Ellis (1976) for Dematiaceous hyphomycetes, Pitt (1985) for Penicillium spp.

\section{Mycotoxins detection by the selected fungal isolates}

Mycotoxin productions by the highly occurrence isolated fungi were detected to determine the percent of toxigenic fungi among the recovered isolates. GlucoseCzapek's broth medium supplemented with $0.2 \%$ yeast extract and $1 \%$ peptone was used for mycotoxins detection by the selected fungal isolates (the highest frequency and occurrence). Each isolate was inoculated in 50 $\mathrm{ml}$ medium and incubated at $28 \pm 1^{\circ} \mathrm{C}$ for 10 days. The content of each flask was homogenized and sonicated with $100 \mathrm{ml}$ chloroform, filtered and dried over anhydrous sodium sulfate. The chloroform layer was evaporated under vacuum and spotted on thin layer chromateography (TLC) plates G60 F254 for the qualitative analysis of mycotoxins. The plates were developed in TLC jars $5 \times 22 \times 22 \mathrm{~cm}$ in diameter (Zeiss, Jena, Germany) saturated with chloroform: methanol (97: 3, v/v). The developed plates were visualized under short wave length $(254 \mathrm{~nm})$ and long wave length $(354 \mathrm{~nm})$ ultraviolet irradiation (UV IS, Desage, Heidelberg, Germany). Mycotoxins were detected and identified in comparison with appropriate reference standards.

\section{Antifungal activity of essential volatile oils against some fungi \\ Ten essential volatile oils including Mint (Mentha sativa), Basil (Ocimum basilicum), Jasmine (Jasminum officinale), (Rose damascene) (Thymus vulgaris), Jojoba (Simmondsia chinensis), Lavender (Lavandula latifolia), Thyme (Thymus vulgaris), Clove (Syzygium aromatic- um), Cinnamon (Cinnamomum verum) and Rosemary}

(Rosmarinus officinalis), extracted previously with the same authors, were tested as antifungal for the selected toxigenic fungal isolates. The antifungal activity of chosen essential oils was evaluated against the tested fungi using the agar well diffusion method. Petri dishes with a diameter of $9 \mathrm{~cm}$ were inoculated by $500 \mu \mathrm{l}$ of fungal spores $\left(10^{6}\right)$ suspension and poured by Saboraud dextrose agar (SDA) medium. Agar wells $(6 \mathrm{~mm}$ in diameter) were prepared using a cork-borer and inoculated by $100 \mu \mathrm{l}$ of natural essential oil. After incubation for 3 days at $28^{\circ} \mathrm{C}$, all plates were examined for formation of inhibition zones around the wells and the diameters of inhibition zones were measured in millimeters.

For determination of the minimal inhibitory concentration (MICs) of the tested volatile oils on the tested fungi, different concentrations $(10,20,30,50,70$ and $100 \% \mathrm{v} / \mathrm{v})$ of the oils were prepared using ethyl alcohol. $100 \mu \mathrm{l}$ of each concentration was inoculated into the agar well of the seeded fungal inoculated plate. The plates were then incubated at $28^{\circ} \mathrm{C}$ for 3 days. MICs were then recorded as the lowest concentration of the tested oil which inhibited fungal growth.

\section{Effect of fumigation of the active volatile oils on spore germination of the tested fungi}

In order to determine the antifungal activity of tested essential oils fumigation on the growth of the tested fungi, fungal spores of each tested fungus were inoculated onto the SDA plates in which $1 \mathrm{ml}$ of each oil was injected on the inside surface of the inverted lid. After incubation at $28^{\circ} \mathrm{C}$ for 4 days, the fungus colony diameter was examined in comparison with the control (Brito et al., 2007).

\section{RESULTS}

\section{Outdoor and indoor fungi of air of Suez General Ho- spital}

Isolation of airborne fungi contaminated the outdoor and indoor atmosphere of Suez General Hospital was conducted and the results presented in table (1). It is obvious that 39 species and two varieties belonging to 13 fungal genera were recovered and identified. View on the diversity of generic level revealed that the genus Aspergillus showed the greatest spectrum by being represented by 11 species and two varieties followed by Penicillium which represented by 11 species. The third fungal genera in order were Alternaria, Cladosporium and Rhizopus represented by three species each. According to the species frequency Aspergillus flavus was the highest and recorded in the six visits $(100 \%)$. On the other hand, according to the colony forming units the genus Aspergillus was the highest in outdoor, reception and intensive care unit (ICU) with 707.4, 569.85, and $432.3 \mathrm{cfu} / \mathrm{m}^{3}$, respectively, followed by Penicillium with $393,216.15$, and $196.5 \mathrm{cfu} / \mathrm{m}^{3}$, respectively (Fig. 1). 


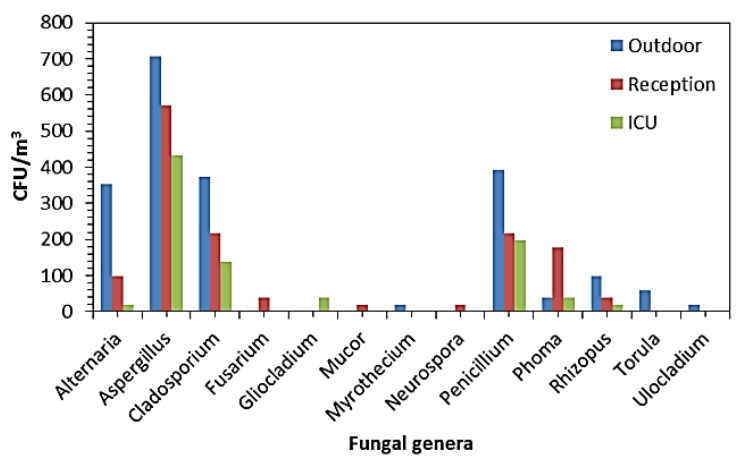

Figure (1): The total colony forming units $\left(\mathrm{cfu} / \mathrm{m}^{3}\right)$ of the isolated fungal genera.

The fungal species Alternaria phragmospora, Aspergillus carbonarius, Aspergillus flavus, Aspergillus niger, Cladosporium herbarum, Penicillium brevicompactum, Penicillium duclauxii, Penicillium expansum and Phoma herbarum were the most common occurrence fungi and recovered from the air of outdoor, reception and ICU of the studied hospital. Comparison between the total colony forming units of the isolated fungi from air of out-door, reception and ICU cleared that the outdoor is more than the indoor sites and the total colony forming units of fungi in intensive care unit are less than of the reception. Also the data shown in figure (2) revealed that the lowest number of fungal genera and species was recovered from the air of intensive care unit whereas the highest number of fungal species was observed in the out-door.

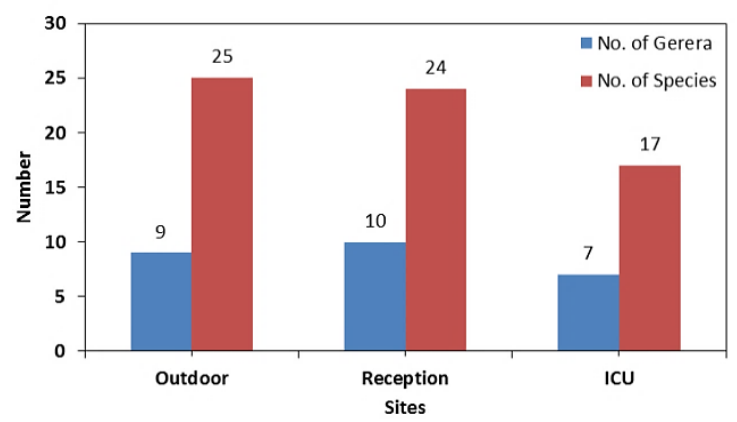

Figure (2): Number of fungal genera and species isolated from the outdoor and indoor air of Suez General Hospital.

It is clear that the survival airborne fungal genera in the intensive care unit were Alternaria, Aspergillus, Cladosporium, Gliocladium, Penicillium, Phoma and Rhizopus. Penicillium was the highest broad spectrum and presented by six species followed by Aspergillus by five species whereas the other remaining genera were represented by one species. All the isolated fungal species from the air of intensive care unit were in low occurrence and frequency except $A$. flavus which recorded in high concurrence $\left(235.8 \mathrm{cfu} / \mathrm{m}^{3}\right)$ and high frequency $(83.33 \%)$ and followed by Cladosporium herbarum as moderate occurrence $\left(137.55 \mathrm{cfu} / \mathrm{m}^{3}\right)$.

Mycotoxin production potential of some isolated fungi in the present investigation

A total of 57 isolates representing 33 species of the fungal genera Aspergillus (11 species), Penicillium (11 species), Cladosporium (3 species), Alternaria (3 species), Phoma (one species), Fusarium (one species), and Rhizopus (3 species), were examined for their potentiality to produce mycotoxins. The results showed that all the tested isolates of the four fungal genera Cladosporium, Cochlibolus, Phoma and Rhizopus could not produce any mycotoxin. On the other hand, the three tested isolates of each of Aspergillus flavus, Penicillium chrysogenum, P. purpurogenum, P. steckii, Alternaria alternata, and Fusarium oxysporum were able to produce mycotoxins and produced aflatoxin $\mathrm{B}^{1}$ and $\mathrm{G}^{1}$, sterigmatocystin, rubratoxin, alternariol, and diacetoxyscirpenol, respectively (Table 2 ). The remaining tested isolates of the other species of Aspergillus and Penicillium were unable to produce the examined mycotoxins.

\section{Antifungal activity of some essential volatile oils aga- inst the isolated toxigenic fungi}

The inhibition effect of ten essential volatile oils on some isolated toxigenic fungi was recorded in table (3). Among the tested essential volatile oils, jasmine, jojoba, lavender, thyme and rosemary showed no antifungal activity against any tested fungal isolate, while the essential oil of cinnamon was showed high significant antifungal activity against all the tested molds. The antifungal activity of the rose essential oil comes next to cinnamon and showed high significant antifungal activity against Alternaria alternata, Aspergillus flavus, Penicillium chrysogenum, Penicillium purpurogenum and Penicillium and steckii, whereas, it showed moderate antifungal activity against Aspergillus niger, and Fusarium oxysporum. Clove essential oil showed high antifungal activity against Alternaria alternata and showed moderate antifungal activity against Fusarium oxysporum, Penicillium purpurogenum and Penicillium steckii and recorded low antifungal activity against Aspergillus flavus, and Penicillium chrysogenum. Based on these observed results, the present study was extended to investigate the minimum inhibitory concentrations of the three active oils, cinnamon, rose and clove on the growth of the tested fungi. 


\section{Occurrence and Frequency of Outdoor and Indoor Airborne Fungi}

Table (1): Total number of colony forming units $\left(\mathrm{cfu} / \mathrm{m}^{3}\right)$ and frequencies percent (out of 6 visits) of airborne fungi of the outdoor, reception and intensive care unit of Suez General Hospital.

\begin{tabular}{|c|c|c|c|c|c|c|c|}
\hline \multirow{2}{*}{\multicolumn{2}{|c|}{ Genera and Species }} & \multicolumn{2}{|c|}{ Outdoor } & \multicolumn{2}{|c|}{ Reception } & \multicolumn{2}{|c|}{ Intensive Care Unit } \\
\hline & & CFU/M $\mathbf{M}^{3}$ & Frequency $\%$ & $\mathrm{CFU} / \mathrm{M}^{3}$ & Frequency \% & CFU/M $\mathbf{M}^{3}$ & Frequency $\%$ \\
\hline \multirow{3}{*}{ Alternaria } & A. alternata & 98.25 & 50.00 & 39.3 & 33.33 & 0 & 0.00 \\
\hline & A. chlamydospora & 216.15 & 33.33 & 0 & 0.00 & 0 & 0.00 \\
\hline & A. phragmospora & 39.3 & 16.67 & 58.95 & 33.33 & 19.65 & 16.67 \\
\hline \multirow{12}{*}{ Aspergillus } & A. carbonarius & 137.55 & 50.00 & 78.6 & 50.00 & 78.6 & 33.33 \\
\hline & A. flavipes & 19.65 & 16.67 & 0 & 0.00 & 19.65 & 16.67 \\
\hline & A. flavus var. columinaris & 58.95 & 33.33 & 117.9 & 50.00 & 0 & 0.00 \\
\hline & A. flavus var. flavus & 334.05 & 100.00 & 176.85 & 83.33 & 235.8 & 83.33 \\
\hline & A. japonicus & 0 & 0.00 & 19.65 & 16.67 & 0 & 0.00 \\
\hline & A. niger & 58.95 & 50.00 & 98.25 & 66.67 & 39.3 & 16.67 \\
\hline & A. oryzae & 19.65 & 16.67 & 0 & 0.00 & 39.3 & 16.67 \\
\hline & A. parasiticus & 0 & 0.00 & 0 & 0.00 & 19.65 & 16.67 \\
\hline & A. restricus & 0 & 0.00 & 19.65 & 16.67 & 0 & 0.00 \\
\hline & A. sydowii & 0 & 0.00 & 19.65 & 16.67 & 0 & 0.00 \\
\hline & A. ustus & 58.95 & 16.67 & 0 & 0.00 & 0 & 0.00 \\
\hline & A. versicolor & 19.65 & 16.67 & 39.3 & 16.67 & 0 & 0.00 \\
\hline \multirow{3}{*}{ Cladosporium } & C. australiensis & 19.65 & 16.67 & 0 & 0.00 & 0 & 0.00 \\
\hline & C. cladosporides & 58.95 & 16.67 & 78.6 & 33.33 & 0 & 0.00 \\
\hline & C. herbarum & 294.75 & 66.67 & 137.55 & 33.33 & 137.55 & 33.33 \\
\hline Fusarium & F. oxysporum & 0 & 0.00 & 39.3 & 16.67 & 0 & 0.00 \\
\hline Gliocladium & G. roseurm & 0 & 0.00 & 0 & 0.00 & 39.3 & 16.67 \\
\hline Mucor & M. circinelloides & 0 & 0.00 & 19.65 & 16.67 & 0 & 0.00 \\
\hline Myrothecium & M. verrucaria & 19.65 & 16.67 & 0 & 0.00 & 0 & 0.00 \\
\hline \multirow[t]{5}{*}{ Neurospora } & N. cristae & 0 & 0.00 & 19.65 & 16.67 & 0 & 0.00 \\
\hline & P. brevicompactum & 117.9 & 33.33 & 39.3 & 33.33 & 19.65 & 16.67 \\
\hline & P. canescens & 0 & 0.00 & 39.3 & 16.67 & 0 & 0.00 \\
\hline & P. chrysogenum & 98.25 & 66.67 & 0 & 0.00 & 39.3 & 33.33 \\
\hline & P. duclauxii & 58.95 & 16.67 & 19.65 & 16.67 & 39.3 & 16.67 \\
\hline \multirow{7}{*}{ Penicillium } & P. expansum & 39.3 & 16.67 & 39.3 & 16.67 & 19.65 & 16.67 \\
\hline & P. funiculosum & 0 & 0.00 & 39.3 & 16.67 & 58.95 & 33.33 \\
\hline & P. griseofulvum & 0 & 0.00 & 0 & 0.00 & 19.65 & 16.67 \\
\hline & P. janthinellum & 39.3 & 33.33 & 0 & 0.00 & 0 & 0.00 \\
\hline & P. puberulum & 0 & 0.00 & 19.65 & 16.67 & 0 & 0.00 \\
\hline & P. purpurogenum & 39.3 & 33.33 & 0 & 0.00 & 0 & 0.00 \\
\hline & P. steckii & 0 & 0.00 & 19.65 & 16.67 & 0 & 0.00 \\
\hline \multirow[t]{2}{*}{ Phoma } & P. herbarum & 39.3 & 16.67 & 176.85 & 50.00 & 39.3 & 16.67 \\
\hline & R. arrhizus & 39.3 & 33.33 & 19.65 & 16.67 & 0 & 0.00 \\
\hline \multirow[t]{2}{*}{ Rhizopus } & R. oryzae & 58.95 & 33.33 & 19.65 & 16.67 & 0 & 0.00 \\
\hline & R. stolonifer & 0 & 0.00 & 0 & 0.00 & 19.65 & 16.67 \\
\hline Torula & T. graminis & 58.95 & 33.33 & 0 & 0.00 & 0 & 0.00 \\
\hline Ulocladium & U. atrum & 19.65 & 16.67 & 0 & 0.00 & 0 & 0.00 \\
\hline Total & & 2063.25 & & 1395.15 & & 884.25 & \\
\hline
\end{tabular}


Table (2): Mycotoxins production by some isolated toxigenic fungi from the outdoor and indoor air of Suez General. Hospital

\begin{tabular}{|c|c|c|c|c|c|c|c|}
\hline Fungal Species & 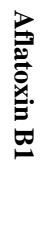 & 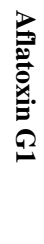 & 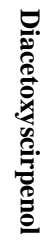 & 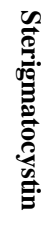 & 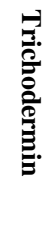 & 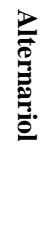 & 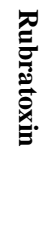 \\
\hline Alternaria alternata & - & - & - & - & - & + & - \\
\hline Aspergillus flavus & + & + & - & - & - & - & - \\
\hline Fusarium oxysporum & - & - & + & - & - & - & - \\
\hline Penicillium chrysogenum & - & - & - & + & - & - & - \\
\hline P. purpurogenum & - & - & - & - & - & - & + \\
\hline P. steckii & - & - & - & - & - & - & - \\
\hline
\end{tabular}

The minimum inhibitory concentrations (MIC) of the three active tested volatile oils against the selected fungi were determined by the agar well diffusion method and recorded in table (3). The MIC of cinnamon oil was 10 $\mu \mathrm{l} / \mathrm{ml}$ medium against Aspergillus flavus and Penicillium steekii and was $5 \mu \mathrm{l} / \mathrm{ml}$ medium against Alternaria alternata, Fusarium oxysporum, Penicillium chrysogenum, and Penicillium purpurogenum. The MIC of rose oil was recorded as $100 \mu \mathrm{l} / \mathrm{ml}$ against Aspergillus flavus and Penicillium purpurogenum, $10 \mu \mathrm{l} / \mathrm{ml}$ for Penicillium steckii and $5 \mu \mathrm{l} / \mathrm{ml}$ for Alternaria alternata, Fusarium oxysporum, and Penicillium chrysogenum.

Table (3): Antifungal activity determined by inhibition zone (IZ) and Minimum inhibition concentration (MIC) of the selected three active volatile oils against the selected toxigenic fungi.

\begin{tabular}{|c|c|c|c|c|c|c|}
\hline \multirow{2}{*}{ Fungal species } & \multicolumn{2}{|c|}{ Rose oil } & \multicolumn{2}{|c|}{ Clove oil } & \multicolumn{2}{|c|}{ Cinnamon oil } \\
\hline & $\begin{array}{c}\mathbf{I Z} \\
(\mathbf{m m})\end{array}$ & $\begin{array}{c}\text { MIC } \\
(\mu 1 / m)\end{array}$ & IZ (mm) & $\begin{array}{c}\text { MIC } \\
(\mu \mathrm{l} / \mathrm{ml})\end{array}$ & $\begin{array}{c}\mathrm{IZ} \\
(\mathrm{mm})\end{array}$ & $\begin{array}{c}\text { MIC } \\
(\mu \mathrm{I} / \mathrm{ml})\end{array}$ \\
\hline $\begin{array}{l}\text { Penicillium } \\
\text { chrysogenum }\end{array}$ & $\begin{array}{c}31 \pm 0 . \\
2\end{array}$ & 5 & $\begin{array}{c}14.5 \pm 0 . \\
3\end{array}$ & 5 & $\begin{array}{c}35.5 \pm \\
0.5\end{array}$ & 5 \\
\hline $\begin{array}{l}\text { Fusarium } \\
\text { oxysporum }\end{array}$ & $\begin{array}{c}17 \pm 0 . \\
1\end{array}$ & 5 & $\begin{array}{c}17.5 \pm 0 . \\
1\end{array}$ & 5 & $\begin{array}{c}40 \pm 0 . \\
1\end{array}$ & 5 \\
\hline $\begin{array}{l}\text { Aspergillus } \\
\text { flavus }\end{array}$ & $\begin{array}{c}25.5 \pm \\
0.1\end{array}$ & 100 & $12 \pm 0.2$ & 100 & $\begin{array}{c}33 \pm 0 . \\
2\end{array}$ & 10 \\
\hline $\begin{array}{l}\text { Alternaria } \\
\text { alternata }\end{array}$ & $\begin{array}{c}25.5 \pm \\
0.1\end{array}$ & 5 & $31 \pm 0.2$ & 5 & $\begin{array}{c}36.5 \pm \\
0.1\end{array}$ & 5 \\
\hline $\begin{array}{l}\text { Penicillium } \\
\text { steckii }\end{array}$ & $\begin{array}{c}31 \\
\pm 0.1\end{array}$ & 10 & $23 \pm 0.5$ & 100 & $\begin{array}{c}34.5 \pm \\
0.2\end{array}$ & 10 \\
\hline $\begin{array}{l}\text { Penicillium } \\
\text { purpurogenum }\end{array}$ & $\begin{array}{c}35 \pm 0 . \\
2\end{array}$ & 100 & $\begin{array}{c}24.5 \pm 0 . \\
3\end{array}$ & 10 & $\begin{array}{c}39 \pm 0 . \\
2\end{array}$ & 5 \\
\hline
\end{tabular}

Effect of fumigation of the selected three active volatile oils on growth of the tested fungi.

The fumigation of both cinnamon and rose oils inhibited spores germination of all tested fungi. However, volatilization of clove oil suppressed the growth of Penicillium chrysogenum and inhibited spores germination of the remaining test fungi. It was obtained from the recorded data that the volatilization vapor of clove essential oil had fungi static activity whereas its direct application showed fungicidal activity (Table 4).
Table (4): Effect of fumigation of the selected antifungal oils on the growth of the isolated toxigenic fungi.

\begin{tabular}{lcccc}
\hline \hline \multicolumn{1}{c}{ Fungal species } & \multicolumn{5}{c}{ Fungal growth } \\
\cline { 2 - 5 } Penicillium chrysogenum & Cont. & Rose & Clove & Cinnamon \\
Fusarium oxysporum & +++ & - & + & - \\
Aspergillus flavus & +++ & - & - & - \\
Alternaria alternata & +++ & - & - & - \\
Penicillium steckii & +++ & - & - & - \\
Penicillium purpurogenum & +++ & - & - & - \\
\hline \hline & +++ & - & - & - \\
\hline
\end{tabular}

\section{DISCUSSION}

The current study investigated the presence of mycobiota in indoor and outdoor air of the common hospital located in Suez, Egypt. The environments of the tested hospital were contaminated with different fungi from 13 genera. Several studies were conducted on the presence and diversity of fungi in outdoor and indoor air of hospitals in different countries of the world (Faure et al., 2002; Augustowska and Dutkiewicz, 2006; Sautour et al., 2009; Panagopoulou et al., 2002; Kuleta et al., 2009; Shams-Ghahfarokhi et al., 2014). In the present study, the fungal genera Aspergillus, Penicillium and Cladosprium recorded the highest frequency among the total isolated fungi followed by Alternaria and Phoma that is consistent with other studies (Gorny and Dutkiewicz, 2002; Perdelli et al., 2006; Tormo-Molina et al., 2012; Goudarzi et al., 2017).

The predominance of these fungal genera may be due to their ability to produce numerous small and light spores that generally borne and scattered by the air, whereas Alternaria, Phoma and some other fungal genera produce fewer, larger and heavier spores which tend to have faster settling (Vonberg and Gastmeier, 2006). Among the Aspergillus species reported in the current study, A. carbonarius and A. flavus were isolated from the two hospitals with a frequency higher than those of other species. This is in accordance with the reports of other researchers on predominance of these species in hospital environments (Pakshir et al., 2007; Sautour et al., 2009; Omoigberale et al., 2014; Paul et al., 2015; Rostami et al., 2017).

The results of the present study show various levels of contamination in all the hospital different sites, even though some areas are equipped with air conditioning systems. Such contamination may be caused by a range of factors, such as, ineffective infection control programs, noncompliance with procedural norms, another reason is due to inefficient operation or inadequate maintenance of the air conditioning system, which can allows unfiltered outside air to enter patient rooms and the crowdedness of patients in reception areas. Another important reason is the using of multi-bed rooms in the intensive care units.

Different fungal genera and species in indoor and outdoor atmosphere especially Penicillium and Aspergillus 


\section{Occurrence and Frequency of Outdoor and Indoor Airborne Fungi}

species were known as mycotoxin-producers (Nielsen, 2003). When fungi common in the atmospheres and house dust were cultivated in building materials, several mycotoxins were produced in vitro (Nielsen, 2003; Nieminen et al., 2002). However, the production of mycotoxins by indoor fungi growing in building materials is much lower (can be absent) than the production in culture medium, probably due to the much lower concentration of nutrients in the former conditions (Nielsen, 2003). Ren et al. (1999) even reported that no mycotoxin production from several Aspergillus strains (isolated from indoor air) growing on building materials (although most of the strains did produce mycotoxins when grown in culture media). A. flavus is occasionally isolated from building materials, and since this species produces the most potent naturally-occurring carcinogen, aflatoxin $\mathrm{B}^{1}$ (Davis et al., 1966; Frisvad and Thrane, 2002). A. ochraceus is occasional isolated in a similar study from building materials, and produces a variety of mycotoxins including ochratoxin A, penicillic acid, xanthomegnin, viomellein, and vioxanthin (Frisvad and Thrane, 2002).

The tested isolates of Alternaria alternata produced alternariol, however the tested isolates of A. chlamydospora and A. phragmospora could not produce any mycotoxin. The Alternaria species predominates in buildings (Andersen et al., 2002; Nielsen et al., 1999). On laboratory media, Alternaria species group produce alternariols, tentoxin, tenuazonic acids, altertoxin I, and a number of unknown metabolites (Andersen et al., 2002). The results also showed that the tested isolate of each of Fusarium lateritium and $F$. poae could not produce mycotoxin, whereas, the tested isolate of $F$. oxysporum produce diacetoxyscirpenol. Sautour et al. (2009) isolated the airborne fungi from outdoor air and indoor two haematological units in a France hospital and recorded Fusarium with low frequency in all cases.

Recently, different studies were conducted to use the essential oils extracted from different plants as a potential way to control fungal contamination (Burt, 2004; Soliman and Badea, 2002; Tajkarimi et al., 2010). The antifungal activity of ten volatile oils (Mint, Basil, Rosemary, Jasmine, Jojoba, Lavender, Thyme, Rose, Clove and Cinnamon) against the isolated toxigenic fungi varied not only from one essential oil to another but also among fungal species. Jasmine, Jojoba, Lavender, Thyme and Rosemary essential volatile oils showed no antifungal activity against any tested fungal isolate. The present study showed that the essential oil of cinnamon was the most active antifungal against the tested fungi and showed high antifungal activity against all the tested molds. In our study we also found that the essential oil extracted from Cinnamon zeylanicum demonstrated strong antifungal activity on both the species of Aspergillus. The antimycotic activity of cinnamon bark due to the presence of cinnamaldehyde is well known (Viollon and Chaumont, 1994). Similarly, in vitro antimicrobial activity of Cinnamon zelyanicum (bark) against human pathogenic fungi and commensally bacteria was studied by Chaumont (2003) and Matan et al. (2006).

The antifungal activity of the rose essential oil comes next to cinnamon and showed high antifungal activity against the tested fungi. In a similar study, Shohayeb et al. (2014) tested the antifungal activity against some species of Aspergillus and Penicillium and reported that the rose oil exerted antifungal activity against the tested fungi. Sukatta et al. (2008) previously reported that the mixing of clove oil and cinnamon oil at appropriate ratios result in an improvement of the efficacy against the postharvest decay fungi of grapes Aspergillus niger and Alternaria alternata. The recorded data indicated that fumigation of the rose, clove and cinnamon oils inhibited the germination and growth of the tested toxigenic fungi and this mean that the using of these oils in mixing with the detergents and other disinfectants in hospitals decrease or inhibit the air pollution by fungi in hospitals, moreover, it will give a good odor without any side effects on the patients.

\section{CONCLUSION}

The present investigation was conducted to identify the outdoor and indoor airborne fungi Suez General Hospital in Suez Governorate, Egypt as well as to control the isolated fungi. The study revealed that a total of 13 fungal genera were isolated from the outdoor and indoor air of the two hospitals. Aspergillus, Penicillium, Cladosporium, Alternaria and Phoma were the most common genera and collected from all the studied sites of Suez General Hospital. Some isolated fungi had the ability to produce mycotoxins for example the isolated Aspergillus flavus produced aflatoxin B. Antifungal activity of some essential oils against the toxigenic fungi was studied and the obtained results revealed that rose, clove and cinnamon oils were active against these fungi and the fumigation of these oils inhibited the spores germination of these fungi. The present study recommends the mixing of these volatile oils with the used disinfectants in the hospitals which will give a safe enjoyable odor by its fumigation and control the fungal contamination.

\section{REFERENCES}

ANDERSEN, B., E. KROGER, AND R.G. ROBERTS. 2002. Chemical and morphological segregation of Alternaria aborescens, A. infectoria and A. tenuissima species groups. Mycol Res; 106: 170-182.

ARAUJO, R., AND J.P. CABRAL. 2010. Fungal air quality in medical protected environments. In Air Quality, Chapter 17. Edited by Kumar A. Croatia: In Tech Open Access Publisher: 357-382.

AUGUSTOWSKA, M., AND J. DUTKIEWICZ. 2006. Variability of airborne microflora in a hospital ward within a period of one year. J Ann Agric Environ Med, 13: 99-106.

BOOTH, C. 1977. Fusarium laboratory guide to the ide- 
ntification of major species. Kew, Surrey, England.

BRITO, E., R. FONTENELLE, R. BRILHANTE, R. CRDEIRO, F. SOARIS A. JUNIOR, MONTERIO, J. SDRIM, AND M. ROSHA. 2007. Phenotypic characterization and in vitro antifungal sensitivity of Candida spp. and $M$. pachydermatis strains from dogs. Vet J, 174: 147-153

BURT, S. 2004. Essential oils: their antibacterial properties and potential applications in foods - A review. Int J Food Microbiol, 94: 223-253.

CENTENO, S., AND S. MACHADO. 2004. Assessment of airborne mycoflora in critical areas of the principal hospital of Cumaná, state of Sucre, Venezuela. Invest Clin, 45 (2): 137-44.

CHAUMONT, J.P. 2003. Antimycotic essential oils: Impact on skin micro flora, in Plant-Derived Antimycotics: Current Trends and Future Prospects (Eds M.K. Rai and D. Mares). Haworth press, USA, 357-364.

DACARRO, C., A.M. PICCO, P. GRISOLI, AND M. RODOLFI. 2003. Determination of aerial microbiological contamination in scholastic sports environments. J Appl Microbiol, 95 (3): 904-12.

DAVIS, N.D., U.L. DIENER, AND D.W. ELDRIDGE. 1966.Production of aflatoxins $\mathrm{B}^{1}$ and $\mathrm{G} 1$ by Aspergillus flavus on a semisynthetic medium. Appl. Microbiol., 14: 378.

DOMSCH, K.H., W. GAMS, AND T.H. ANDER-SON, 1980. Compendium of soil fungi. London: Academic Press.

DOUWES, J. AND N. PEARCE. 2003. Invited commentary: Is indoor mold exposure a risk factor for asthma? American Epidemiol., 158 (3): 203-206.

ELLIS, M. B. 1976. More Dematiaceous hyphomycetes. Kew, Surrey, England: Commonwealth Mycological Institute.

FAURE, O., H. FRICKER-HIDALGO, B. LEBEAU, M. R. MALLARET, P. AMBROISE-THOMAS, AND R. GRILLOT. 2002. Eight year surveillance of environmental fungal contamination in hospital operating rooms and haematologic units. J Hosp Infect, 50: 155-60.

FERNSTROM, A., AND M. GOLDBLATT. 2013. Aerobiology and its role in the transmission of infectious diseases. J Pathogens, 6: 1-13.

FRISVAD, J.C., AND U. THRANE. 2002. Mycotoxin production by common filamentous fungi. In: Samson, R. A.; E. S. Hoekstra, J. C. Frisvad, and O. Filtenborg. (Eds.), Introduction to Food and Air Borne Fungi, sixth ed. Centraalbureau voor Schimmelcultures, Utrecht, 321-330.

GORNY, R. L., AND J. DUTKIEWICZ. 2002. Bacterial and fungal aerosols in indoor environment in Central and Eastern European countries. Ann Agric Environ Med, 9: 17-23.

GOUDARZI, G., Z. SOLEIMANI, B. SADEGHINEJAD, M. ALIGHARDASHI, S.M. LATIFI, AND M.MORADI. 2017. Visiting Hours Impact on indoor to Outdoor Ratio of Fungi Concentration at Golestan University Hospital in Ahvaz, Iran. Environment and Pollution, 6(1): 62.

HOEKSTRA, E.S., R.A. SAMSON, AND R.C. SUMMERBELL. 2004. Methods for the detection and isolation of fungi in the indoor environment. In: Introduction to Food and Airborne fungi (eds: Samson R. A. Hoekstra E. S. and Frisvad, J. C.), 298-305.

KULETA, M., RAPALA-KOZIK AND K. ANDRZEJ. 2009. Fungi pathogenic to humans: molecular bases of virulence of Candida albicans, Cryptococcus neoformans and Aspergillus fumigatus. Acta Biochimica Polonica, 56 (2): 211-224.

LI, C. AND P. HOU. 2003. Bioaerosol characteristics in hospital clean rooms. The Sci of the Total Environ, 305 (1-3): 169-76.

LI, D.W., AND C.S. YANG. 2004. Fungal contamination as a major contributor to sick building syndrome. Advances in Applied Microbiology, 55: 31-112.

MATAN, N., H. RIMKEEREE, A.J. MAWSON, P. CHOMPREEDA, V. HARUTHAITHANASAN, AND M. PARKER. 2006. Antimicrobial activity of cinnamon and clove oils under modified atmosphere conditions. Int J Food Microbiol, 107 (2): 180-5.

MOUBASHER, A.H. 1993. Soil fungi in Qatar and other Arab countries. Doha, Qatar: The Scientific and Applied Research Centre, University of Qatar: 566.

NIELSEN, K.F. 2003. Mycotoxin production by indoor molds. Fungal Genetics and Biology, 39 (2): 103 177.

NIELSEN, K.F., S. GRAVESEN, P.A. NIELSEN, B. ANDERSEN, U. THRANE, AND J.C. FRISVAD, 1999. Production of mycotoxins on artificially and naturally infested building materials. Mycopathologia, 145: 43-56.

NIEMINEN, S.M., R. KÄRKI, S. AURIOLA, M. TOIVOLA, H. LAATSCH, R. LAATIKAINEN, A. HYVÄRINEN, AND A. VON WRIGHT. 2002. Isolation and identification of Aspergillus fumigatus mycotoxins on growth medium and some building materials. Applied and Environmental Microbiology, 68 (10): 4871-4875.

OMOIGBERALE, M.N., O.O. AMENGIALUE, AND M.I. IYAMU. 2014. Microbiological assessment of hospital indoor air quality in Ekpoma, Edo State, Nigeria. Global Res J Microbiol, 4(1): 1-5.

PAKSHIR, K., G. SHEKARKHAR, S. MOSTAGNIE, B. SABAYAN, AND A. VAGHEFIKIA. 2007. Monitoring of airborne fungi in two general hospitals in Shiraz, Southern Iran. Iran J Med Sci, 32 (4): 240-244.

PANAGOPOULOU, P., J. FILIOTI, G. PETRIKKOS, P. GIAKOUPPI, M. ANATOLIOTAKI, AND E. FARMAKI. 2002. Environmental surveillance of filamentous fungi in three tertiary care hospitals in 


\section{Occurrence and Frequency of Outdoor and Indoor Airborne Fungi}

Greece. J Hosp Infect 2002, 52: 185-191.

PAUL, D., K. BISWAS, C. SENGUPTA, AND S. N. SINHA. 2015. Studies on Environmental Monitoring of Aeromicroflora in a Hospital at Kalyani, West Bengal, India. Frontiers Environ Microbiol, 1 (3): 47-50.

PERDELLI, F., M.L. CRISTINA, A. M. SPAGNOLO, B.S. DALLERA, G. OTTRIA, AND M. GRIMALDI. 2006. Fungal contamination in hospital environments. Infect Control Hosp Ep, 27: 44-47.

PITT, J.I. 1985. A laboratory guide to common Penicillium species. North Ryde: Division of Food Research, Commonwealth Scientific and Industrial Research Organization.

PORTNOY, J.M., K. KWAK, P. DOWLING, T. VANOSDOL, AND C. BARNES. 2005. Health effects of indoor fungi. Annals of Allergy, Asthma and Immunology, 94 (3): 313-320.

RAINER, J., U. PEINTNER AND R. PÖDER. 2000. Biodiversity and concentration of airborne fungi in a hospital environment. Mycopathologia, 149 (2):8797.

RAPER, K.B., AND P.I. FENNELL. 1965. The genus Aspergillus. Baltimore, USA: William and Wilkins.

REN, P., T.M. JANKUN, AND B.P. LEADERER. 1999. Comparisons of seasonal fungal prevalence in indoor and outdoor air and in house dusts of dwellings in one Northeast American county. Journal of Exposure Analysis and Environ. Epidemiol., 9 (6): 560-568.

ROSTAMI, N., H. ALIDADI, H. ZARRINFAR, AND P. SALEHI. 2017. Assessment of indoor and outdoor airborne fungi in an Educational, Research and Treatment Center. Italian j medic, 11(1): 52-56.

SAUTOUR M , N. SIXT, F. DALLE, C. L'OLLIVIER, V. FOURQUENET, C. CALINON, K. PAUL, S. VALVIN, A. MAUREL, S. AHO, G. COUILLAULT, C. CACHIA, O. VAGNER, B. CUISENIER, D. CAILLOT, A. BONNIN. 2009. Profiles and seasonal distribution of airborne fungi in indoor and outdoor environments at a French hospital. J. Science of the Total Environment, 407: 3766-3771.

SHAMS-GHAHFAROKHI, M., S. AGHAEI-GHAREH BOLAGH, N. ASLANI, AND RAZZAGHIABYANEH, M. 2014. Investigation on distribution of airborne fungi in outdoor environment in Tehran, Iran. J Environ Health Sci Eng, 12(1): 54.

SHELTON, B.G., K.H. KIRKLAND, W.D. FLANDERS, AND G. K. MORRIS. 2002. Profiles of airborne fungi in buildings and outdoor environments in the United States. Applied and Environ. Microbiol., 68 (4): 1743-1753.

SHOHAYEB, M., E.S. ABDEL-HAMEED, S.A. BAZAID, AND I. MAGHRABI. 2014. Antibacterial and Antifungal Activity of Rosa damascena MILL. Essential Oil, Different Extracts of Rose Petals. Global J Pharm 8 (1): 01-07.

SOLIMAN. K.M., AND B. I. BADEA. 2002. Effect of oil extracted from some medicinal plants on different mycotoxigenic fungi. Food Chem Toxicol., 40: 1669-1675.

STRYJAKOWSKA-SEKULSKA., M. A. PIOTRASZE WSKA-PAJĄK, A. SZYSZKA., M. NOWICKI. AND M. FILIPIAK. 2007. Microbiological quality of indoor air in university rooms. Polish J. of Environ. Stud, 16 (4): 623-632.

SU, H. J., P.C. WU, H.L. CHEN, F. C. LEE, AND L. L. LIN. 2001. Exposure assessment of indoor allergens, endotoxin, and airborne fungi for homes in Southern Taiwan. Environmental Research, 85 (A):135-144.

SUKATTA, U., V. HARUTHAITHANASAN, W. CHANTARAPANONT, U. DILOKKUNANANT, AND P. SUPPAKUL. 2008. Antifungal activity of clove and cinnamon oil and their synergistic against postharvest decay fungi of grape in vitro. Kasetsart $\mathbf{J}$ (Natural Science), 42: 169-174.

TAJKARIMI, M.M., S.A. IBRAHIM, AND D.O. CLIVER. 2010. Antimicrobial herb and spice compounds in food. Food Control, 21: 1199-1218.

TORMO-MOLINA, R., M.A. GONZALO-GARIJO, S. FERNANDEZ-RODRIGUEZ, AND I. SILVAPALACIOS. 2012. Monitoring the occurrence of indoor fungi in a hospital. Rev Iberoam Micol, 29: 227-234.

VIOLLON, C., AND J.P. CHAUMONT. 1994. Antifungal properties of essential oils and their main components upon Cryptococcus neoformens. Mycopathologia, 128: 151-153.

VONBERG, R. P., AND P. GASTMEIER, 2006. Nosocomial aspergillosis in outbreak settings. J Hosp Infect, 63 (3): 246-254. 
تواجد وكثافة الفظريات المحمولة في الهواء الخارجى والاخلى لمستثفى السويس العام، السويس، مصر

\author{
عبدالحميد رسمى، أكرم أبوسعدة، ايمان البيلى \\ قسم النبات و الميكروبيولوجى، كلية العلوم، جامعة السويس، السويس، مصرئ اليلفر \\ الملخص العربي
}

هدفت هذه الدراسة إلى تحديد تواجد وكثافة الفطريات في الهواء الطلق والداخلي (الاستقبال والرعاية المركزة) في مستشفى الهنى

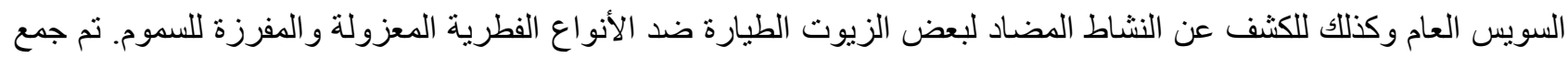
العينات من خلال الترسيب المباشر باستخدام طريقة ترسيب الاطباق. تم تعريض اطباق الوسط الغذائى السابورود دكستروز أجار

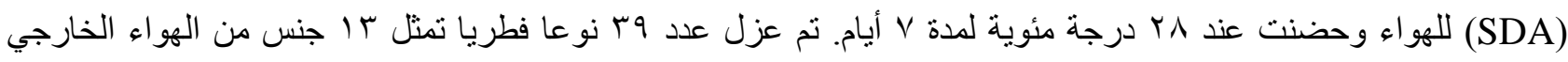

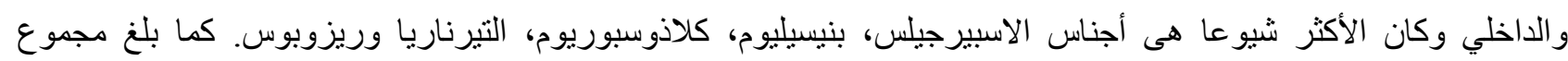

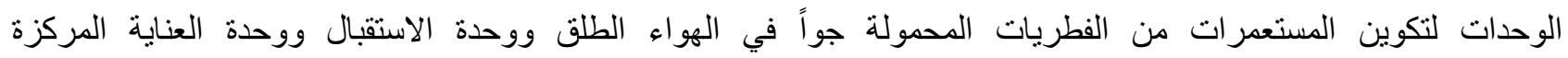

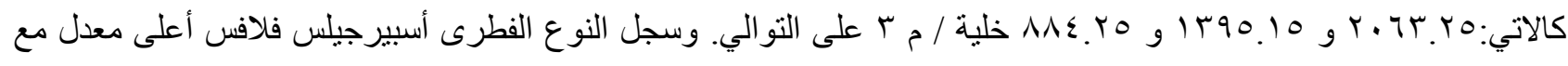

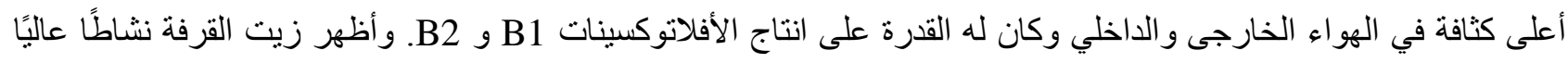
ضد الفطريات المعزولة المفرزة للسموم الفطرية، وكما أدى تبخير الزيت إلى تثئيط إنبات جر اثثيم هذه الفطريات. 